\begin{tabular}{|c|c|c|}
\hline \multicolumn{3}{|c|}{ PublisherInfo } \\
\hline PublisherName & & BioMed Central \\
\hline PublisherLocation & & London \\
\hline PublisherImprintName & & BioMed Central \\
\hline
\end{tabular}

130591474-760XGenome BiologyGenome BiolLife SciencesAnimal Genetics and GenomicsHuman GeneticsPlant Genetics \& GenomicsMicrobial Genetics and GenomicsBioinformaticsEvolutionary BiologyBiomedical and Life Sciences441211292

CoverDate : 2003-12-

The Author(s)2003

\title{
Compromise reached over German copyright bill
}

\begin{tabular}{||l|l|l||}
\hline \multicolumn{2}{|c|}{ ArticleInfo } \\
\hline \hline ArticleID & $:$ & 4747 \\
\hline \hline ArticleDOI & $:$ & $10.1186 /$ gb-spotlight-20030411-01 \\
\hline \hline ArticleCitationID & $:$ & spotlight-20030411-01 \\
\hline \hline ArticleSequenceNumber & $:$ & 99 \\
\hline \hline ArticleCategory & $:$ & Research news \\
\hline \hline ArticleFirstPage & $:$ & 1 \\
\hline \hline ArticleLastPage & $:$ & 3 \\
\hline \hline ArticleHistory & & RegistrationDate : 2003-4-11 \\
\hline \hline ArticleCopyright & $:$ & OnlineDate \\
\hline \hline ArticleGrants & $:$ & BioMed Central Ltd2003 \\
\hline \hline ArticleContext & $:$ & \\
\hline \hline
\end{tabular}


For months, academic publishers, scientists, libraries, and legislators in Germany have been entangled in a row over a new digital copyright bill. On Wednesday, a compromise was finally reached.

The EU directive on digital copyright should have been implemented into national law by the end of last year, but only a few of the 15 member states have done so to date. The intention is to enable scientists to share information for research and teaching purposes while at the same time protecting the interests of copyright owners.

But in Germany, the digital copyright bill has angered academic publishers. They fear the new law could make the distribution of unauthorized copies easier than ever before, and may thus have "disastrous consequences" for the publishing trade. In particular, they argue that university libraries could use the new law to save money by digitizing copyrighted work and making it freely available to other libraries.

"This is all lies and deliberate misinformation," said Ulf Gerder, a spokesperson for the justice ministry. "Paragraph 52a [which sparked off the row] does not even mention libraries."

"The right to make digital copies is a pretty harmless issue, and for libraries of no interest whatsoever," agreed Friedrich Geißelmann, chair of the German Libraries Association. He suspects that the aim of the publishers' campaign is to strengthen their stance and attack alternative publishing models.

Indeed, there is a powerful debate in Germany about how to enable scientists to make their work more widely available. The growing open-access movement involves national and international initiatives such as Hamburg University Press, Math-Net, Open Archives Initiative and the Budapest Open Access Initiative. Proponents of open-access publishing models argue that the bill blocks the way to a free information society.

Following heated debates in the national press last week, the German Parliament's legal committee decided yesterday to strike a compromise between the opposing sides. The wording of the controversial paragraph 52a will not be changed, but during a transitional period that will end in 2006, its implementation will be under close scrutiny. If the publishers' worries become reality, the bill will be corrected.

Are all sides now happy? Ulf Gerder is concerned that the media coverage last week made people aware of opportunities to abuse the copyright law. "This won't be news to computer hackers, but through the publishers' campaign, the issue got wide publicity. I wonder whether the publishers scored an own goal."

The law is expected to be passed by the Bundestag Friday (April 11). It will then have to go through the upper house (Bundesrat), probably in May. 


\section{References}

1. German Booksellers and Publishers Association, [http://www.boersenverein.de/]

2. Justice ministry, [http://www.bmj.bund.de/eng/news/?sid=c6437469c774fee6c6c256380bd9eddb]

3. German Libraries Association, [http://www.bibliotheksverband.de/]

4. Hamburg University Press, [http://www.hup.rrz.uni-hamburg.de]

5. Math-Net, [http://www.math-net.de/]

6. Open Access Initiative, [http://www.openarchives.org]

7. Budapest Open Archives Initiative, [http://www.soros.org/openaccess/]

This PDF file was created after publication. 